\title{
The role of metrics in food policy: Lessons from a decade of experience in New York City
}

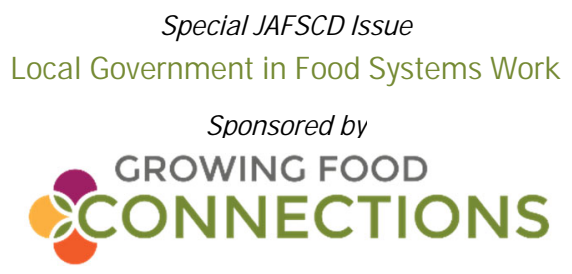

Nicholas Freudenberg, ${ }^{\text {* }}$ Craig Willingham, ${ }^{\text {a }}$ and Nevin Cohen a

CUNY Urban Food Policy Institute at the City University of New York

Submitted January 4, 2018 / Revised March 19, May 19, and July 18, 2018 / Accepted May 21, 2018 /

Published online O ctober 17, 2018

Citation: Freudenberg, N., Willingham, C., \& Cohen, N. (2018). The role of metrics in food policy:

Lessons from a decade of experience in New York City. Journal of A griculture, F ood Systems, and C ommunity

D evelopment, 8(Suppl. 2), 191-209. https:/ / doi.org/ 10.5304/ jafscd.2018.08B.009

Copyright ( 2018 by the Authors. Published by the Lyson Center for Civic Agriculture and Food Systems. Open access under CC BY license.

\begin{abstract}
In the last decade, New York City developed food policies designed to improve access to healthy food, reduce food insecurity, support community development, promote sustainable food systems, and improve conditions for food workers. Since 2012, the New York City Council has mandated the Mayor's Office to prepare annual Food Metrics Reports to present data on selected food system indicators. This article uses these reports to assess how the metrics describe the city's progress in implementing municipal food policies set in the last decade. O ur analysis examines: (1) changes in the indicators that the city reports; (2) strengths and weaknesses of the Food Metrics Reports as a tool
\end{abstract}

a Nicholas Freudenberg, Craig Willingham, and Nevin Cohen are with the CUNY Urban Food Policy Institute at the City University of New York G raduate School of Public Health and Health Policy.

* Corresponding author: Nicholas Freudenberg, CUNY Urban Food Policy Institute, 55 West 125th Street, New York, New York 10027 USA; Nick.Freudenberg@ sph.cuny.edu for monitoring policy enactment and impact; and (3) opportunities for improvements to the indicators and the development and implementation of future metrics. We found that the reports show improvements in $51 \%$ of the 37 indicators and sub-indicators, declines in 40\% and no change or no assessment in the remaining indicators. While the food metrics process has provided valuable data on the implementation of selected city food policies, it has several limitations. By adding new indicators, tapping into additional data sources, and engaging additional constituencies in the process, New York City food metrics could play a more useful role in helping New York City to set goals

\section{Funding Disclosure}

We thank the New Y ork Community Trust and its Wilhelm Lowenstein Memorial Fund and Food Samaritan Fund for the support of this project.

\section{Author Note}

The opinions expressed and the accuracy of the evidence cited in this article are the responsibility of the authors and not our advisers or employer. 
and monitor progress towards the development of a more equitable, efficient, and sustainable municipal food system. The experience with food metrics in New Y ork City suggests lessons for the use of food policy monitoring to improve food systems in other cities.

\section{Keywords}

Urban Food Policy, Food Metrics, Municipal Food Systems, Food System Assessments

\section{Introduction}

In the last decade, New Y ork City has instituted many new food policies and programs designed to improve access to healthy food, reduce food insecurity, support community and economic development, promote a more sustainable food system, and improve pay and conditions for food workers (Freudenberg, Cohen, Poppendieck, \& Willingham, 2018; Willingham, Rafalow, Lindstrom, \& Freudenberg, 2017). While New Y ork City's food policies have been examined in the academic literature (Freudenberg, Silver, Hirsch, \& Cohen, 2016; Isett, Laugesen, \& Cloud, 2015; Cohen \& Reynolds, 2014; Freudenberg \& Atkinson, 2015; Campbell, 2016; Roberto, Swinburn, Hawkes, Huang, Costa, Ashe, \& Brownell, 2015; Lederer, Curtis, Silver, \& Angell, 2014), the role of metrics in the food policy process, and the strengths and limitations of current food metrics, have been under-studied, despite the close connection between metrics and policy choices.

This paper analyzes six Food Metrics Reports prepared annually by the New York City Mayor's Office of Food policy since 2012 to assess how the metrics describe the city's progress in carrying out various municipal food policies. O ur analysis examines: (1) changes in the indicators measured by the metrics the city reports; (2) strengths and weaknesses of the Food Metrics Reports as a tool for monitoring policy implementation and impact; and (3) opportunities for improvements in three domains: the indicators, the process of metrics development, and the implementation of future metrics that would make the metrics more useful for evaluation and planning. O ur goal is to identify lessons from the city's experience with food metrics that can inform food policy planning, implementation, and evaluation in other cities. This article is based on a comprehensive study assessing the city's progress since 2008 in achieving five broad food policy goals: improving nutritional well-being, promoting food security, creating food systems that support economic and community development, ensuring a sustainable food system, and supporting food workers (Freudenberg et al., 2018). These policy goals are briefly defined in Table 1.

\section{Metrics and Policy}

An assessment of the strengths and weaknesses of New Y ork City's food metrics requires a brief review of recent developments in the application of metrics to food and other policy arenas. Metrics, also known as indicators, are mechanisms that measure the condition of a system or that represent a system's characteristics. They usually do so through a mix of quantitative or qualitative variables (Feenstra, Jaramillo, McG rath, \& Grunnell, 2005; Waas et al., 2014). Accurate and reliable metrics are considered important for evidencebased public policy and management. There is also a long history of their use in addressing a wide range of policy issues, from equality and social justice to public health and ecological sustainability (Bell \& Morse, 2013). The use of metrics has grown in recent years as the cost of large-scale data collection (i.e., "big data") and the tools to analyze and visualize large quantities of data have dropped and become more accessible to agency staff, advocates, and the public (Kitchin, Lauriault, \& McArdle, 2015; A they, 2017).

Metrics serve several different purposes in the policy process. A common view is that metrics play an instrumental role in the evaluation and assessment of policies (Sébastien \& Bauler, 2013) by measuring activities and outcomes, often through a reduced or simplified set of variables that represent more complex systems. Metrics allow policies to be tracked. If data are conveyed in a form that government officials, advocates, businesses, and the public can understand and use, the data can be used to measure impact, costeffectiveness, comparative costs and benefits, longitudinal change, geospatial differences, and other variables. These are all examples of variables 
that can help avert unintended negative consequences and achieve desired outcomes. At best, the development and analysis of metrics can serve as a catalyst for the democratic public discussion of policy goals.

Metrics can also drive decision-making processes. The choice of indicators influences our perception of policy problems and shapes our approach to solving them (Barrett, 2010). Metrics are socially constructed, and the social process of metrics development can facilitate shared understandings of problems and desired outcomes, engage actors in the policy process (Innes, 1990), or present a partial or distorted view of reality. By focusing attention on certain outcomes over others, some metrics can serve to exclude people. The recognition that indicators can reinforce existing structures and policies led to the social indicators movement of the 1960s and 1970s. This movement aimed to develop alternative measures of progress and engage citizens in indicator development (Talberth, Cobb, \& Slattery, 2007; Meadows, 1998). The importance of locally developed indicators has been embraced by advocacy organizations and global programs like the Local Agenda 21 planning process (Pires, Fidélis, \& Ramos, 2014).

The adage, "what gets measured gets managed" over-simplifies the impacts of metrics on policy. The instrumental and social dimensions of metrics enable them to make the policymaking process more or less democratic in several ways: (1) by providing decision-makers and advocates with common evidence; (2) by limiting access to particular sources and types of data; (3) by substituting information for action, thereby delaying change; (4) by framing concerns like equity or health as technocratic issues, thereby limiting political debate; or (5) by strategically communicating metrics to support predetermined positions (Hezri \& D overs, 2006).

\section{The Growth of Urban Food Metrics}

Cities have collected data about urban food systems, from food adulteration to urban agriculture, since the emergence of public health and food planning at the turn of the 20th century (Vitiello \& Brinkley, 2014). The focus on collecting metrics on the environment and health accelerated in the 1970s as federal and state laws required a wide range of indicators to be measured and reported. But it was not until the early 2000s, as the urban food system became a legitimate focus of urban planners and policymakers, that cities started developing discrete food metrics, initially focused on urban sustainability (Heller \& Keoleian, 2003). USD A published guidelines for food security metrics in 2002 (Cohen, 2002), and philanthropic organizations and non-profits launched initiatives like the Vivid Picture Project, an effort in 2004-5 to create indicators of California's food system and benchmarks to gauge the system's sustainability (Feenstra et al., 2005). Though criticized for reinforcing rather than challenging policies and norms (G uthman, 2008), Vivid Picture and other food metrics projects focused attention on the process of food system metrics development, the validity of the measures, and the application of metrics to policy.

Within the past two decades, national and international programs have accelerated the development of local and regional food system indicators to track and compare (or "benchmark") food systems management. Prosperi, Moragues, Sonnino, and Devereux (2015) compared the use of food system metrics in eight such projects. In 2015, the Institute of Medicine and National Research Council published a framework for assessing food systems that included recommended metrics (Institute of Medicine and National Research Council, 2015; Clancy, 2016). Following the adoption of the United Nations Sustainable Development G oals (SD Gs) in 2015, scholars have examined how the collection of urban food systems data on hunger, food security, nutrition, and sustainable agriculture, as well as social equity, public health, and ecological sustainability coincide with the indicators required to show attainment of the SD Gs (Marmot \& Bell, 2018; Ilieva, 2017).

At the city scale, the proliferation of food system plans, strategies, and policy papers over the past decade has been the impetus for municipal governments to develop and collect urban food systems metrics (Coppo, Stempfle, \& Reho, 2017; Ilieva, 2017). An analysis of the content of food strategies and plans from five North A merican 
cities (New York, Philadelphia, Los Angeles, Chicago, and Toronto) identified 260 distinct food system indicators in these cities alone (Ilieva, 2017). Food systems strategies sometimes contain definitions of how goals and objectives are to be measured, but the level of specificity and degree to which cities, regional planning agencies, or other entities (e.g., food policy councils) are expected to collect and report data vary significantly. Municipal indicators are typically derived from pre-existing government data, data collected by academic institutions and $\mathrm{NGOs}$, and proprietary data from private sector firms. D ifferent data collection and reporting methods and frequencies, geographic boundaries, definitions, and limited or inconsistent data availability result in inconsistencies in the information collected within and across cities (Ilieva, 2017; Coppo et al., 2017). In another example, the Milan Urban Food Policy Pact plans to release a set of indicators to guide the 132 signatories to the Pact in tracking their progress achieving the commonly agreed-upon goals (Food and Agriculture O rganization [FAO ] of the United Nations, 2017).

\section{Food Metrics in N ew York City}

Food policy became politically salient in New York City about a decade ago (Freudenberg et al., 2018). Appendix 1 shows some of the policy and programs implemented since 2005 by New Y ork City and New York State, each of which has jurisdiction over several domains of food policy in the city. Yet, despite the reputation of the Bloomberg administration (2001-2013) for having a datadriven government (Kelly, D avies, G reig, \& Lee, 2016), food metrics were not systematically collected and disseminated. City departments like Health, Parks, Sanitation, and Environmental Protection published information about the food and agriculture programs under their jurisdictions, yet there was no process for regularizing the data collection and no central repository of the data. Even the city's 2007 sustainability strategy, PlaNYC, which detailed more than 100 initiatives of 25 agencies (O ffice of the Mayor of New York City, 2007) with measurable milestones, did not include food policies until a 2011 update (Office of the Mayor of NYC, 2011).

\section{F oodW orks}

Food metrics in New York City was an outcome of F oodW orks, a food systems strategy document launched as an initiative of City Council Speaker Christine Quinn in 2009 (New York City Council Speaker, 2010). F oodW ork s was designed to be a comprehensive plan that proposed "new policies and investments [that] can encourage positive changes for the food system of future generations." The report described the city's existing food policies and programs and outlined "key legislative changes, public and private investments, infrastructure improvements, and partnerships to improve [the city's] food system" (Brannen, 2010, p. 2), including policy recommendations that extended beyond the jurisdictional and physical boundaries of the city (Campbell, 2016).

During the Council's work on F oodW orks, it became apparent that there were gaps in the basic data about the food that the city buys and serves and the impact of various food-related programs (New Y ork City Council, 2011a). The first report, released in 2012, described the document as "a resource for New Y orkers to better understand our food system and how municipal government plays a role" (New Y ork City Mayor's Office of Food Policy, 2012, p. 1).

\section{F ood M etrics L egislation}

After releasing FoodWorks, the Speaker introduced a "package" of food bills in 2011 to implement several of the initiatives in F oodW ork s (Cohen, 2011). In response to gaps in available data about the food system, a core aim was to ensure that indicators of food strategies outlined in $\mathrm{F}$ oodW orks were collected and made available to the Council and advocates to monitor progress in implementing the food strategy. Council staff began by identifying relevant indicators for the strategies proposed in F oodW orks and then developed legislation requiring politically feasible metrics that were logistically possible to collect to be reported.

The Council introduced three bills requiring agencies such as the Departments of Health and Mental Hygiene, City Planning, and Education, among others, to produce: (1) a list of all cityowned real estate and the potential for vacant parcels to be used for urban agriculture; (2) an 
annual report of New York State food products procured by city agencies for their institutional food programs compared to purchases from outside of New Y ork during the state's growing season; and (3) an "omnibus" metrics bill covering 19 different indicators for activities under the jurisdiction of different agencies. The Mayor's Office opposed these mandates, claiming they imposed unfunded burdens on agencies that had already faced budget cuts after the 2008 global financial crisis (Campbell, 2016). Testimony on the legislation by representatives of the Administration stressed the difficulty (and costs) of collecting data on issues like the provenance of food procured by city agencies or the suitability of city-owned property for food production (New Y ork City Council, 2011b).

In response to these concerns and to ensure the that the legislation was passed by the Council and signed by the Mayor, the Speaker's legislative staff entered negotiations with Administration staff and amended the food metrics legislation to address issues raised by the Administration. The changes included: (1) extending the deadline for the first reporting period; (2) specifying that for metrics requiring information from vendors and other third parties, city agencies were only obligated to request such data and report it to the extent it is available; (3) removed metrics "where it was not possible to ease the burden of collection from third parties;" and (4) revised metrics to allow agencies to report similar information that the agency already collects or could collect within existing budgetary resources (NYC Council, 2011c). Following these changes, the City Council passed, and the Mayor signed, Local Law 52. Appendix 2 shows the indicators included in Local Law 52. While these changes enabled final approval of Local Law 52, they limited the scope of what was monitored and reduced the utility of the reports.

This legislation established annual reporting requirements for the first time for many foodrelated initiatives (New York City Mayor's O ffice of Food Policy, 2012). Local Law 52 assigned responsibility for the annual reports to the Mayor's Office of Long Term Planning and Sustainability, the agency also responsible for tracking the city's sustainability strategies and collecting data to assess progress in meeting sustainability goals. In practice, this responsibility was assumed by the Mayor's O ffice of Food Policy, created in 2007. The data for these indicators are collected by the responsible city agency and submitted to the Office of the Director of Food Policy in the Mayor's O ffice, whose staff then aggregates the indicators into the annual report, capturing a snapshot of the work agencies are doing within the city's food system. The Food Metrics Report illustrates the intersectoral scope of food policy in New York City through indicators that cut across numerous sectors, including public health, education, food waste, and urban planning. In 2013, the City Council passed a new law requiring additional metrics on levels of food insecurity in New York City (New York City Council, 2013).

Three governance factors shaped Local Law 52. First, New York City's "strong mayor" form of government gives the Mayor sole authority to estimate the city's budget and manage all city agencies (Eichenthal, 1990). While the City Council legislates and must approve the Mayor's budget, it has relatively little authority over agency commissioners; however, the City Council does have the authority to conduct public hearings in which they scrutinize the progress of an agency in carrying out its duties. Requiring the city to submit annual metrics on the outcomes of food policies and programs provides the Council with the opportunity to monitor the progress of new food initiatives and hold commissioners accountable. As a City Council staff report on the Local Law 52 observed, "to adequately monitor and address the challenges facing New Y ork City's food system, policymakers and members of the public must have access to full and accurate information." (New York City Council, 2011a, p. 4).

Second, the food metrics legislation also served to draw attention to elements of F oodW ork s for which future City Council members and civil society groups could advocate. Thus, it was a more practical and less politically contentious, although perhaps less effective, effort to set policy goals without enacting legislation and authorizing funding for every issue addressed.

Finally, the Food Metrics Reports were a way for the Speaker to solidify support among 
advocates for stronger food policies. Requiring comprehensive food metrics was a way to demonstrate her office's commitment to these issues and to provide advocates with annual data that would help them in their efforts to hold agencies accountable, as testimony in support of the legislation from advocates from food justice, environmental and anti-hunger organizations illustrated (New York City Council, 2011b).

\section{Metrics as Assessment Tools}

As shown in Table 1, the Food Metrics Report tracks 37 separate indicators in the 19 categories listed in Appendix 2. The main purpose of these indicators is to measure progress in implementing major food policies. We examined the city's Food Metrics Reports between 2012 and 2017 to assess changes in five broad policy goals (shown in the left column of Table 1) that we had identified in another comprehensive study of food policy in New York City (Freudenberg et al., 2018).

For each indicator, we assessed the change between 2012 and 2017. When data were not reported for 2012, we used the earliest subsequent year available for comparison. For each indicator, we determined whether the observed change represented an improvement, decline, no change, or no assessment. We used the intent of the policy instrument that authorized the program or policy to make this classification. When two investigators disagreed about the classification, we discussed the assignment to reach a consensus.

Of the indicators tracked between 2012 and 2017, 51\% (19) showed improvements, 40\% (15) showed declines (often by small amounts), one showed no change, and two were not assessed. To evaluate progress across policy domains, we assigned each indicator to one of the five policy goals, then assessed the change in this indicator reported between 2012 and 2017. We recognized that some policies may contribute to two or more of these goals. However, we assigned each to the single primary goal that we thought best reflected the policy authorizing that activity.

Table 1. Distribution of Food Metrics Indicators by Goals and Direction of Change

\begin{tabular}{|c|c|c|c|c|c|}
\hline Policy Goals & $\begin{array}{l}\text { Number of } \\
\text { Indicators }\end{array}$ & $\begin{array}{l}\text { Improvements } \\
\text { in indicator }\end{array}$ & $\begin{array}{l}\text { Declines in } \\
\text { indicator }\end{array}$ & $\begin{array}{l}\text { No change in } \\
\text { indicator }\end{array}$ & Not reported \\
\hline $\begin{array}{l}\text { 1. Improve nutritional well-being. Policies } \\
\text { that promote health and reduce diet- } \\
\text { related diseases }\end{array}$ & 21 & 10 & 8 & 1 & 2 \\
\hline $\begin{array}{l}\text { 2. Promote food security. Policies that } \\
\text { reduce hunger and food insecurity and } \\
\text { provide the quality and quantity of food } \\
\text { needed to maintain health }\end{array}$ & 4 & 4 & 0 & 0 & 0 \\
\hline $\begin{array}{l}\text { 3. Create food systems that support } \\
\text { economic } \& \text { community development. } \\
\text { Policies that promote community } \\
\text { economic development through food and } \\
\text { improve food production and distribution } \\
\text { in the region }\end{array}$ & 3 & 1 & 2 & 0 & 0 \\
\hline $\begin{array}{l}\text { 4. Ensure a sustainable food system. } \\
\text { Policies that reduce food waste and food- } \\
\text { related pollution and carbon emissions } \\
\text { and protect the region's farmland }\end{array}$ & 8 & 3 & 5 & 0 & 0 \\
\hline $\begin{array}{l}\text { 5. Support Food Workers. Polices that } \\
\text { provide food workers with decent wages } \\
\text { and benefits, safe working conditions, } \\
\text { and the right to organize }\end{array}$ & 1 & 1 & 0 & 0 & 0 \\
\hline Total & 37 & $\begin{array}{c}19 \\
(51 \%)\end{array}$ & $\begin{array}{c}15 \\
(40 \%)\end{array}$ & $\begin{array}{c}1 \\
(3 \%)\end{array}$ & $\begin{array}{c}2 \\
(5 \%)\end{array}$ \\
\hline
\end{tabular}


$\mathrm{N}$ utrition and F ood A coess $\mathrm{G}$ oals. The most frequently assigned goal for the policies monitored in the Food Metrics Report was to improve nutritional well-being. This was the primary goal assigned to 21 of the 37 policies (57\%). Of these 21 indicators, $10(48 \%)$ showed improvements, 8 (38\%) showed declines, one showed no change, and two were not assessed.

Some examples of the activities implemented to achieve this goal include:

- Between 2012 and 2017, the Food Retail Expansion to Support Health (FRESH), a city program to encourage supermarkets to open or expand in low-income neighborhoods, approved 27 new supermarkets, of which 14 had been completed by the end of 2017.

- The number of food stores participating in Shop Healthy, an initiative to expand access to healthy food in bodegas and supermarkets, increased from 161 in 2012 to 1,117 in 2017.

- In both 2012 and 2017, the compliance rate with New Y ork City Food Standards, the rules that mandate less sugar, fat, and salt in the meals and snacks served by 11 city agencies in their institutional food programs, was more than $90 \%$.

- The number of snack and beverage vending machines in NYC public schools declined slightly, and the inclusion of healthier fare that complied with NYC Food Standards led to a $16 \%$ decline in revenues from these machines.

- Salad bars were installed in all city schools by 2016, with the number of salad bars increasing by $38 \%$ in six years.

On several other nutrition and access indicators, the Food Metrics Reports showed declines:

- The number of meals and snacks served in the city's institutional food programs declined by 11\%, from 271 million in 2012 to 242 million in 2017. Of 12 New York City municipal programs serving food in both years, the number of meals and snacks served in 2017 compared to 2012 declined for nine and increased for only three. In some cases, the cause seems clear. For example, reduction in the city's jail population led to the need for fewer meals while an increase in the number served by homeless shelters led to a $48 \%$ increase in the number of meals served in shelters, a dramatic indicator of a growing problem. The largest food-serving institution, the New York City school system, reported 800,000 fewer meals were served in 2017 than in 2012, a 4\% decline.

- G reen Cart vendors sell fruits and vegetables on street corners in low-income neighborhoods. The number of $\mathrm{G}$ reen $\mathrm{Cart}$ permits declined by 37\% between 2012 and 2017. The number with Electronic Benefits Transfer (EBT) systems, which allow customers to purchase produce with their SNAP benefits, increased by $14 \%$. However, the number of carts with EBTs fell sharply between 2016 and 2017.

- G reenmarkets and farmers markets provide many New Y orkers with access to fresh, locally grown produce. The number of farmers market and $\mathrm{G}$ reenmarket locations fell slightly between 2012 and 2017 although many new ones were in lowincome neighborhoods.

F ood seaurity. Of the four indicators assessing food security initiatives, all showed some progress:

- The number of older people getting SNAP benefits increased by 25\%. However, between 2000 and 2014, the number of people aged 65-74 in New York increased by $24 \%$. This suggests that some of the observed increase in the number of seniors receiving SNAP benefits may be the result of population growth, not increased enrollment rates. In addition, New Y ork City's older adults experienced an increase in poverty from $16.5 \%$ in 1990 to $19.3 \%$ in 2014. This suggests that more seniors are eligible for SNAP now than in earlier periods (New York City D epartment for 
the Aging, 2016).

- The number of sites providing SNAP enrollment services increased by $45 \%$, and funding for enrollment activities increased by $12 \%$.

- The number of SNAP recipients receiving nutrition education between 2012 and 2015 increased 14-fold and spending on this increased by $10 \%$. No information is available on the procedures used to count participants.

Several measures included in the nutritional well-being section may also contribute to reducing food insecurity, including the number of $\mathrm{Green}$ Carts accepting EBTs, the system that allows them to accept SNAP, and the number of FRESH supermarkets opened in under-served neighborhoods.

In 2014, as required by the 2013 City Council addition to the Food Metrics Report, the first Food Metrics report released by the newly elected de Blasio Administration added data on the number of New York City residents reported to be food insecure. In 2012, this report showed that 1.4 million New Y ork City residents, $17.4 \%$ of the population, were food insecure. The Meal Gap-that is, the number of meals missing from the homes of families and individuals struggling with food insecurity--was reported to be 250 million meals. The 2017 Report, using self-reported data from the 2015 Feeding America Survey, reported that 1.25 million New Yorkers, $14.9 \%$ of the population, were food insecure and the Meal Gap was 224.8 million meals. Between 2012 and 2015, the self-reported rate of food insecurity fell by $14 \%$ and the number of missing meals fell by $10 \%$. These were both significant achievements that reduced the pernicious effects of poverty in New York City.

Community and E conomic D evelopment. Two indicators assessed the contribution of food programs to community and economic development. The number of community gardens on city-owned property increased by 32\% between 2012 and 2017. An estimated 1,200 lots are used as community gardens in New York City (Nir, 2016), suggesting newly registered community gardens account for about $11 \%$ of the total. In 2015, NYC's affordable housing plan proposed to build new housing on 14 community gardens ( $\mathrm{Nir}, 2016)$.

Between 2012 and 2017, the New Y ork City Economic Development Corporation and the Industrial D evelopment Agency made 161 awards totaling US\$14.3 million to food manufacturers. Funding levels and the number of awards stayed about the same over those years.

Sustainable food systems. Four of the eight indicators that assess progress towards a more sustainable food system showed improvements:

- The number of acres of farmland participating in the New York City's D epartment of Environmental Protection (DEP) watershed protection program increased by $6 \%$ between 2012 and 2017. The number of acres covered ranged from a high of 26,359 in 2014 to a low of 18,735 in 2012.

- There was a $5 \%$ decrease in the number of farms participating in the DEP watershed agricultural program in 2017 compared to 2012; there was a 6\% increase in the number of acres covered.

- Between 2012 and 2017, New York City increased annual spending on local milk, yogurt, and produce by $9 \%$. In 2016, the D epartment of Education's spending on local food accounted for $12 \%$ of its total O ther Than Personnel Services (OTPS) expenditures on food services (New York City D epartment of Education, 2016).

- An $80 \%$ decline was reported in the number of daily truck trips to or through the Hunts Point Food Market, and a 45\% decline was reported in daily rail trips. These changes are associated with a reduction in air pollution.

Sustainability indicators that showed negative trends between 2012 and 2017 were a 5\% decline in the number of farms participating in the city's watershed protection program; a 59\% reduction in city financial support to upstate farms participating in the watershed protection program; and a $65 \%$ 
decline in city spending on the more environmentally friendly large containers of bottled water for city agencies and a 35\% increase in spending on the more wasteful single-serve containers.

Food W ork ers. The single indicator that assessed support for food workers showed a $24 \%$ increase in the number of workers trained by the city's Small Business Services between 2014 and 2017. The 324 trainees who received training in 2017 represented a tiny fraction of the city's 63,000 grocery store workers and the 320,000 who work in food service and drinking establishments.

\section{What are the strengths and weaknesses of the Food Metrics Reports as a tool for monitoring policy implementation and impact?}

The Food Metrics Reports provide valuable data for understanding the implementation of city food initiatives. As the only compendium of food data published by the city, they offer evidence for an assessment of progress in implementing selected food policies approved in New York City over the last decade or so. This makes Metrics Reports an important step forward in food policy planning. The fact that the Reports show measurable progress in the implementation of $51 \%$ of the indicators provides assurance that a bare majority of implementation measures for food initiatives are moving in the right direction. The findings on the lack of progress in $40 \%$ of the indicators show the need for additional efforts.

The production of six annual reports and their findings are a tribute to the determined efforts of two Mayoral Administrations and the City Council to improve food policy in New York City. The reports and the reporting process are also the results of consistent advocacy, education, policy monitoring, and community mobilization for more effective and equitable food policies by a variety of community organizations, civic groups, and the emerging New York City food movement.

But, the Food Metrics reporting process could be more useful to the food planning process in several ways. As our summary indicates, they provide a somewhat scattershot view of city food policy. The lack of geographical analysis precludes their use by community leaders who want to compare their neighborhoods to other city neighborhoods. Most indicators lack denominators for the population to be served, preventing their use to assess the reach of existing programs. The metrics do not include numerous other sources of public data on food, blocking policymakers and advocates from utilizing the full range of data that is collected to inform policymaking. Moreover, by using fixed metrics the profile they draw is of a static system; however, as Meter (2011) has observed, food systems are in fact dynamic and complex, an insight reinforced by our findings.

Most fundamentally, the lack of any organizing framework or articulated food policy goals for New Y ork City and the focus of the selected metrics on implementation rather than outcomes limits their use in assessing progress toward broader food policy goals. While our summary of the Metrics Reports provides tantalizing and useful snapshots of food policy in action in New York City over the last six years, it does not provide meaningful answers to whether New York City is making progress towards achieving the five goals shown in Table 1. In the next section, we suggest how New York and other cities can take steps to address these limitations.

\section{Food Metrics Reports 2.0: Toward a Comprehensive Food Plan for New York City}

What changes in the Metrics indicators and process might make the reports more useful for strengthening food policy, improving food governance, and creating a more equitable and efficient municipal food system? Six years of experience with the Food Metrics Reports provides a foundation for considering Food Metrics 2.0, an expanded approach to food planning that builds on the successes and limitations of the last decade of food policy in New York City. O ur suggestions are intended to encourage conversation among food planners in other cities, New Y ork City and state policymakers, public officials in the many agencies that have food responsibilities, food advocates, food businesses, and community leaders and residents. 
1. Indude denominators as well as numerators for relevant metrics.

Few of the indicators provide a denominator that allows the reader to interpret the significance of the change reported or to assess the population impact of the results. For example, Indicator 1 reports the number of farms and their acreage participating in the DEP watershed agricultural programs but not the total acreage of farmland in the region or state. Other evidence shows that the acreage protected since 2012 accounts for only a small fraction of the farmland in these watersheds (Watershed Agricultural Council, 2017). Similarly, without knowing the number of children enrolled each year in city schools, the number who are served school lunches has little meaning. Several other indicators would benefit from denominator data and specified targets for achieving policy goals.

2. Select additional indicators.

Through the political deliberations we described, in 2011 the City Council somewhat arbitrarily selected several indicators for the Metrics Reports. As the city considers its food policy goals for the next decade, it should identify indicators that will add new insights and guide policy to solve emerging problems. Especially welcome additions would be measures that capture emerging and dynamic dimensions of the food system (Meter, 2011), e.g., the changing patterns of the retail availability of food by neighborhood. O ther metrics to consider are the number of individuals or households eligible for public food programs but not enrolled, the number of retailers who accept SNAP or other benefits by community district, the density of fast food establishments, and the number and percent of various sub-populations experiencing food insecurity (e.g., immigrants, college students, and older people). By assessing the feasibility, benefits, and cost of adding such additional indicators, the creators of the reports could select new indicators that could lead to more useful monitoring of food policy in the coming years.

3. A dd other sources of data and create a unified publidy available data platform.

New Y ork City and State agencies report food data in several other formats, including the Mayor's
Management Report, annual city Budget Reports, the New Y ork City D epartment of Health's annual Community Health Surveys and its restaurant inspection data, the D epartment of Education's reports on the use of school meals, and the New Y ork State D epartment of Agriculture and Markets' food retail database. Policy-makers and residents could realize the potential of using Big D ata to inform policy by aggregating these multiple sources into a single user-friendly database that could be used to assess municipal and local food environments.

In addition, in the last decade the city has commissioned several reports that have produced point-in-time data on characteristics of the food system that warrant ongoing monitoring. Examples include studies on the special distribution of supermarkets and grocery stores (New York City D epartment of City Planning, 2008), the sources of New York City's food supply (Barron et al., 2010), and the transportation of food within the city (New Y ork City Economic D evelopment Corporation, 2016). Two major Mayoral strategic plans, Mayor Bloomberg's 2011 Update of PlaNYC (Office of the Mayor of NYC, 2011) and Mayor de Blasio's O neNYC (O ffice of the Mayor of NYC, 2015) also present goals and data on the city's food system and on other sectors. The first uses a sustainability lens to plan for the city's future, the second an equity lens. Each plan provides a useful framework for intersectoral food planning but has been divorced from the food metrics process.

In 2012, the City Council passed an Open Data Law requiring all city public datasets to be published on the O pen Data Portal, which by 2017 included more than 1600 datasets (Hopkins, 2017). By using open access platforms such as New York City O pen Data, the site that makes these data more widely available, an expanded food metrics initiative could assist public agencies, community leaders, advocates, and academics to participate more effectively and equitably in food policy governance.

4. Indude more constituencies inside and outside city government in the metrics process.

Creating, analyzing, and using mutually agreed on 
metrics to monitor and inform food policy has the potential to engage diverse constituencies in shaping those policies. Conversely, restricting the process to a few public officials limits the opportunity for public discussion and collective ownership of the process.

Improvements in food policy require an intersectoral perspective in which many municipal agencies work together to enhance their cumulative contributions. The Food Metrics Report already includes data from the D epartments of Health, Education, and Environmental Protection, the Human Resources Administration, Small Business Services, Economic D evelopment Corporation, and others. By enlisting these agencies in defining and collecting data on other outcomes that contribute to better food systems, the Mayor's O ffice of Food Policy could begin to monitor other outcomes that contribute to reductions in food insecurity and diet-related diseases.

For example, increases in the minimum wage or decreases in residential rent puts more money in the pockets of low-income residents, enabling them to spend more on food (Cohen, 2016). Changes in commercial rent influence the profitability of food stores. By expanding its intersectoral focus, the food metrics process could keep track of a wider range of influences on diet and food systems. This would allow food metrics to identify emerging problems and to inform preventive policy measures.

Another group that could contribute to and benefit from more extensive involvement in the food metrics process is academics. They could assist the city to improve the quality and transparency of the data used in the report, identify other useful metrics, and design small-scale studies to inform the metrics process. They could also suggest qualitative methods that would yield evidence that could help to assess why policies were succeeding or failing.

Further attention to the knowledge systems by which various constituencies use data such as those in the Food Metrics Reports to influence food policy could also enhance their utility. Asking community leaders, advocates, and policymakers, as Cash et al. (2003) have suggested, about what they need to know might increase the utility of the reports. For example, enabling community leaders to localize data might help to identify, then reduce inequitable access to healthy affordable food. O ne way to broaden participation in the metrics process may be for the City Council to hold hearings on the food metrics reports. This would provide its authors with an opportunity to answer questions and explain findings and its users an opportunity to make suggestions for improvements.

\section{Mak e equity a priority.}

Food policy scholars suggest that promoting more equitable distribution of healthy urban food environments should be a high priority for food planners (Dixon, O mwega, Friel, Burns, D onati, \& Carlisle, 2007; Hawkes \& Halliday, 2017). D espite more than a decade of attention to food policy, the New Y ork City's progress in reducing the prevalence of inequities in its most serious food problems--food insecurity and hunger, diet-related diseases, the adverse environmental impact of our food system, and the low wages and poor working conditions of food workers--have been at best modest (Freudenberg et al., 2018).

By using metrics to chart progress towards reducing socioeconomic and racial and/ or ethnic inequities in the distribution of food insecurity and diet-related diseases, New Y ork City can begin to realize the current Mayor's commitment to making New York City the "fairest big city" in the nation (O ffice of the Mayor of NYC, 2018). In addition, the city government can use Mayoral equity initiatives in other sectors to increase food equity. For example, expanding the supply of affordable housing in ways that also increase access to affordable healthy food, making food a central component of universal pre-kindergarten programs, and including food workers in workforce development programs to increase the number of good jobs in New York could amplify the equity impact of each of these initiatives (Cohen, 2016; O ffice of the Mayor of NYC, 2015, 2017). Measuring the success of such efforts could help the food metrics process put equity front and center.

Various strategies have been used to highlight inequities in food-related outcomes across neighborhoods and populations. For example, a 
comparison of food environments in neighborhoods with varying $G$ ini coefficients, a common measure of inequality used to represent the income or wealth distribution of an area's residents, can highlight inequitable outcomes and opportunities for action (Raja, Ma, \& Y adav, 2008). Another effort established indicators for food outcomes (e.g., the percentage of high school students who eat fruits and vegetables five or more times per day), tracked the outcomes identified by a community coalition across neighborhoods and assessed progress towards achieving five-year goals in reducing inequalities (Healthy Kids Healthy Communities Buffalo, 2013). Engaging community residents and leaders in setting, collecting, and interpreting measures of inequality can increase their capacity to tackle the conditions that produce these disproportionate burdens.

\section{F ocus on outcomes as well as implementation} The goal of food policy is to improve the wellbeing of the population and provide more equitable access to healthy food for all sectors of the population. Food metrics can help to achieve this goal by clearly defining the pathways by which implementing programs and policies leads to desired short-term impact and long-term outcomes. For example, improving access to affordable fruits and vegetables seeks to improve diet quality, reduce food insecurity, and shrink inequities in diet-related diseases. To assess progress towards this goal, a metrics process could examine the associations between the implementation of a host of programs and policies (e.g., G reen Carts, supermarket expansion incentives, New York Food Standards, fruit and vegetable prescriptions) and the changes in daily fruit and vegetable consumption by community and population group. By looking at the cumulative impact of several policy initiatives related to key outcomes, New York City could begin to track progress towards its broader goals.

7. Present analyses and frameworks for interpreting changes in metrics as well as describing them

The current Food Metrics Reports present data on selected indicators but provide no analyses of progress, no compelling rationale for why New
Yorkers want to track such outcomes, and little analysis of the reasons for successes or failures. What entity or entities conducts such analyses, whether it is the Mayor's O ffice, the City Council, civil society groups, or some combination, deserve public discussion. But collecting and reporting metrics without providing a publicly-accessible rationale or deeper analysis is like a baseball umpire calling balls and strikes but never recording runs or outs. While readers of the reports can make their own determination, this does not provide a solid foundation for policy development.

\section{Conclusion}

O ur recommendations suggest a few ways in which the metrics process could be developed in the coming years to provide more useful evidence to guide food policy in New York City. Most essential, in our view, New Y ork City needs a comprehensive, intersectoral multi-year food plan. The purpose of monitoring food policy indicators is to track progress in achieving goals; without clearly articulated objectives, food metrics become less useful. While we acknowledge the challenges in deciding who should develop such a plan and finding the resources necessary for its implementation, it seems unlikely that New York City will make progress in reducing its most significant food problems without a clear roadmap to guide who should be doing what.

In our view, the process of developing such a plan should be participatory, time-limited, and guided by the available evidence. O ne approach might be to first set a few specific 5- to-10-year objectives for each of the five broad policy goals shown in Table 1 and then begin aligning current policies and identifying gaps to fill to achieve those objectives. Many other cities have developed multiyear food plans, including London (Cretella, 2015; London Food Link, 2016), Chicago (City of Chicago, 2013), Los Angeles (Los Angeles Food Policy Council, 2017) and Toronto (Mah \& Thang, 2013), and their experiences can help guide New York City. In addition, international partnerships such as the Milan Urban Food Pact (Tegoni \& Licomati, 2017) and recent reports on urban food policy governance (Hawkes \& Halliday, 2017) have also begun to suggest approaches to using data to 
inform municipal food planning.

In the last decade, New Y ork City has made significant progress in creating and implementing new food policies. The annual Food Metrics Reports have been an important part of the process, and they remain the most comprehensive documentation of the city's progress in food policy. In the coming years, New York City - and other big cities- will need to incorporate the lessons learned from the first years of the food metrics process, build on its successes, and minimize its limitations to use the monitoring process to inform the development of a comprehensive food plan. By doing so, New York City and other big cities can increase the likelihood that, five or ten years from now, they will be able to show substantial progress in creating healthier, more efficient, more equitable, and more sustainable urban food systems.

\section{Acknowledgments}

We thank Molly Hartman, Kim Kessler, Jan Poppendieck, Charmaine Ruddock, Ben Thomases, and Barbara Turk for their helpful suggestions on an earlier draft. We thank the editors and anonymous reviewers at the Journal of A griculture, Food Systems, and C ommunity D evelopment for their suggestions.

\section{References}

Athey, S. (2017). Beyond prediction: Using big data for policy problems. Scienœ, 355(6324), 483-485. https:// doi.org/ 10.1126/ science.aal4321

Barrett, C. B. (2010). Measuring food insecurity. Science, 327(5967), 825-828. https:/ / doi.org/ 10.1126/ science.1182768

Barron, M., Goldblatt, B., Ho, C., Hudson, R., Kaplan, D ., Keberle, E.,... Wilson, M. (2010). U nderstanding N ew Y ork City's food supply. New Y ork: Columbia University School of International and Public Affairs. Retrieved from https:/ / sipa.columbia.edu/ academics/ capstone-projects/ understanding-new-york-city\%E2\%80\%99s-food-supply$\underline{0}$

Bell, S., \& Morse, S. (2013). Towards an understanding of how policy making groups use indicators. E ological indicators, 35, 13-23. https:/ / doi.org/ 10.1016/ j.ecolind.2012.12.023

Brannen, S. (2010). FoodW ork s: A vision to improve N Y C's food system. The New York City Council. Retrieved from http:// ngfn.org/resources/ngfn-database/ knowledge/ foodworks fullreport_11_22_10.pdf

Campbell, L. K. (2016). G etting farming on the agenda: Planning, policymaking, and governance practices of urban agriculture in New Y ork City. U rban F orestry \& U rban G rening, 19, 295-305. https:// doi.org/ 10.1016/ j.ufug.2016.03.011

Cash, D. W., Clark, W. C., Alcock, F., Dickson, N. M., Eckley, N., G uston, D. H.,... Mitchell, R. B. (2003). Knowledge systems for sustainable development. Proceedings of the N ational A cademy of Sciences, 100(14), 8086- 8091.

https:// doi.org/ 10.1073/ pnas.1231332100

City of Chicago D epartment of Housing and Economic D evelopment. (2013). A recipe for healthy places: A ddressing the intersection of food and obesity in Chicago. Retrieved from https:/ / www.cityofchicago.org/ content/ dam/ city/ depts/ zlup/ Sustainable D evelopment/ Publications/ Recipe Fo r Healthy Places/ Recipe for Healthy Places Final.pdf

Clancy, K. (2016). The many uses of a new report on food systems assessments. Journal of A griculture, Food Systems, and Community D evelopment, 6(2), 9-12. http:// dx.doi.org/ 10.5304/ jafscd.2016.062.006

Cohen, B. E. (2002). Community food security assessment toolkit. Washington, D .C.: United States D epartment of Agriculture, Economic Research Service. Retrieved from https:/ / www.ers.usda.gov/ publications/ pub-details/ ?pubid=43179

Cohen, N. (2011). FoodWorks legislative package scheduled for vote [Blog post]. Urban Food Policy blog, accessed at https:/ / urbanfoodpolicy.com/ 2011/ 07/ 27/ foodworks-legislative-package-scheduled-for-vote/

Cohen, N. (2016). Illuminating the "hidden" food policies of the de Blasio administration. CUNY Urban Food Policy Institute Policy Brief. Retrieved from http:/ / www.cunyurbanfoodpolicy.org/ news/ 2016/ 7/ 19/ illuminating-thehidden-food-policies-of-the-de-blasio-administration

Cohen, N., \& Reynolds, K. (2014). Urban agriculture policy making in New Y ork's "new political spaces." Journal of Planning E ducation and Research, 34(2), 221-234. https:/ / doi.org/ 10.1177/ 0739456X 14526453 
Coppo, G., Stempfle, S., \& Reho, M. (2017). Urban food strategies and plans: Considerations on the assessment construction. City, T erritory and A rchitecture, 4(1), 8. https:/ / doi.org/ 10.1186/ s40410-017-0064-2

Cretella, A. (2015). Beyond the Alternative Complex: The London Urban Food Strategy and neoliberal governance. M étropoles, 17, 1-18. http:/ / journals.openedition.org/ metropoles/ 5147

Dixon, J., O mwega, A. M., Friel, S., Burns, C., D onati, K., \& Carlisle, R. (2007). The health equity dimensions of urban food systems. Journal of U rban H ealth, 84(1), 118-129. https:/ / doi.org/ 10.1007/ s11524-007-9176-4

Eichenthal, D . (1990). The other elected officials. In J. Bellush \& D. Netzger (Eds.), U rban Politics N ew Y ork Style (pp. 86-106). Armonk, NY: ME Sharp.

Feenstra, G., Jaramillo, C., McG rath, S., \& Grunnell, A. N. (2005). Proposed indicators for sustainable food systems. D avis, CA: Ecotrust. Retrieved from http:/ / coloradofarmtoschool.org/ wp-content/ uploads/ downloads/ 2013/ 02/ Proposedindicators-for-sustainable-food-systems.pdf

Food and Agriculture Organization [FAO] of the United Nations. (2017, O ctober). Building opportunities for local food policies: U rban monitoring framework. Presentation at the $3^{\text {rd }}$ Milan Urban Food Policy Pact G athering and Mayors' Summit, Valencia, Spain. Retrieved from http:// www.milanurbanfoodpolicypact.org/ wpcontent/ uploads/2017/ 12/ FAO MUFPP-monitoring-framework-Valencia.pdf

Freudenberg, N., \& A tkinson, S. (2015). G etting food policy on the Mayoral table: A comparison of two election cycles in New York and London. Public H ealth, 129(4), 295-302. https:/ / doi.org/ 10.1016/ j.puhe.2015.02.018

Freudenberg, N., Cohen, N., Poppendieck, J. \& Willingham, C. (2018). F ood policy in N ew Y ork City sinœ 2008: L essons for the next decade. CUNY Urban Food Policy Institute. Retrieved from https:/ / static1.squarespace.com/ static/572d0fcc2b8dde9e10ab59d4/t/ 5a8c6ed371c10b0805e7b25f/ 151915285722 4/ SPH+Monitor+V2+Long Final2.pdf

Freudenberg, N., Silver, M., Hirsch, L., \& Cohen, N. (2016). The good food jobs nexus: A strategy for promoting health, employment, and economic development. Journal of A griculture, F ood Systems, and Community D evelopment, 6(2), 283301. https:/ / doi.org/ 10.5304/ jafscd.2016.062.020

Guthman, J. (2008). Thinking inside the neoliberal box: The micro-politics of agro-food philanthropy. G eoforum, 39(3), 1241-1253. https:// doi.org/ 10.1016/ j.geoforum.2006.09.001

Hawkes, C., \& Halliday, J. (2017). W hat makes urban food policy happen? Insights from five case studies. International Panel of Experts on Sustainable Food Systems. Retrieved from http:// www.ipes-food.org/ images/Reports/Cities full.pdf

Healthy Kids Healthy Communities Buffalo. (2013). Indicators for a healthy food and built environment in the city of Buffalo: W here we are and where we need to go. Retrieved from https:/ / ubwp.buffalo.edu/ foodlab/ wpcontent/ uploads/sites/68/2017/ 06/40_D elgado_Norton_Raja_2013_RajaEd_IndicatorsforaHealthyFoodandBuilt EnvironmentinBuffalo UB1.pdf

Heller, M. C., \& Keoleian, G. A. (2003). Assessing the sustainability of the US food system: A life cycle perspective. A gricultural Systems, 76(3), 1007-1041. https:/ / doi.org/ 10.1016/ S0308-521X (02)00027-6

Hezri, A. A., \& D overs, S. R. (2006). Sustainability indicators, policy and governance: Issues for ecological economics. E cological E conomics, 60(1), 86-99. https:/ doi.org/ 10.1016/ j.ecolecon.2005.11.019

Hopkins, D . (2017, May 4). Q \&A: A look at NYC's open data approach with Mayor's Senior Project Manager [Blog post]. Retrieved from Carto blog: https:/ / carto.com/ blog/ qa-nyc-open-data-approach/

Ilieva, R. T. (2017). Urban food systems strategies: A promising tool for implementing the SD G s in practice. Sustainability, 9(10), 1707. https:// doi.org/ 10.3390/ su9101707

Innes, J. E. (1990). Knowledge and public policy: The search for meaningful indicators. New Brunswick, NJ: Transaction Publishers.

Institute of Medicine \& National Research Council. (2015). A framework for assessing effects of the food system. Washington, D .C.: The National Academies Press. https:/ / doi.org/ 10.17226/ 18846

Isett, K., Laugesen, M., \& Cloud, D . (2015). Learning from New Y ork City: A case study of public health policy practice in the Bloomberg Administration. Journal of Public H ealth M anagement and Pradice, 21 (4), 313.

https:// doi.org/ 10.1097/ PHH.0000000000000225 
Journal of Agriculture, Food Systems, and Community D evelopment

ISSN: 2152-0801 online

https:// www.foodsystemsjournal.org

Kelly, P. M., D avies, A., G reig, A. J., \& Lee, K. K. (2016). O besity prevention in a city state: Lessons from New Y ork city during the Bloomberg Administration. F rontiers in Public H ealth, 4. https:/ / doi.org/ 10.3389/ fpubh.2016.00060

Kitchin, R., Lauriault T. P., \& McArdle, G. (2015). Knowing and governing cities through urban indicators, city benchmarking and real-time dashboards. Regional Studies, Regional Scienœ, 2(1), 6-28. Retrieved from https:// rsa.tandfonline.com/ doi/ full/ 10.1080/ 21681376.2014.983149\#.W5xJFq2Z O u4

Lederer, A., Curtis, C. J., Silver, L. D ., \& Angell, S. Y. (2014). Toward a healthier city: Nutrition standards for New York City government. A merican Journal of Preventive M edicine, 46(4), 423-428. https:/ / doi.org/ 10.1016/ j.amepre.2013.11.011

London Food Link. (2016). G ood F ood 2016 for L ondon. H ow L ondon boroughs can help seare a healthy and sustainable food future. Retrieved from https:/ / www.sustainweb.org/ publications/ good food for london_2016/ \#

Los Angeles Food Policy Council. (2017). Good Food for All agenda, 2017. Retrieved from http:/ / goodfoodla.org/ 2017/ 11/ 13/ good-food-for-all-agenda-2017/

Mah, C. L., \& Thang, H. (2013). Cultivating Food Connections: The Toronto Food Strategy and municipal deliberation on food. International Planning Studies, 18(1), 96-110. https:/ / doi.org/ 10.1080/ 13563475.2013.750941

Marmot, M., \& Bell, R. (2018). The Sustainable D evelopment G oals and health equity. E pidemiology, 29(1), 5- 7. https:// doi.org/ 10.1097/ ED E.0000000000000773

Meadows, D . (1998). Indicators and information systems for sustainable development: A report to the Balaton G roup. Hartland Four Comers, VT: The Sustainability Institute.

Meter, K. (2011). Seventeen reasons to do better food system assessments. Journal of A griculture, Food Systems, and Community D evelopment, 2(1), 7-10. https:/ / doi.org/ 10.5304/ jafscd.2011.021.014

New York City Council. (2011a). Report of the Governmental Affairs Division, Committee on G overnmental Operations. June 16, 2011. Retrieved from http:/ / legistar.council.nyc.gov/ LegislationD etail.aspx?ID =917941\&G UID =52D AF6BB-3710-4840-98ED07AEA1EFC9AD

New York City Council. (2011b). Transcript of Public Hearings on Local Law 52, New Y ork City Council, June 16, 2011. Retrieved from http:/ / legistar.council.nyc.gov/ LegislationD etail.aspx?ID =917941\&G UID =52D AF6BB3710-4840-98ED-07AEA1EFC9AD

New York City Council. (2011c). Report of the G overnmental Affairs Division, Committee on G overnmental Operations. July 27, 2011. Retrieved from http:/ / legistar.council.nyc.gov/ LegislationD etail.aspx?ID =917941\&G UID =52D AF6BB-3710-4840-98ED07AEA1EFC9AD

New York City Council. (2013). Local Law to amend the New York city charter and the administrative code of the city of New York, in relation to assessing food security. Retrieved from http:/ / legistar.council.nyc.gov / LegislationD etail.aspx?ID =1520864\&GUID =953D 129F-2808-48E 0-9E 9D D3C577E 7D CFF

New York City Council Speaker Christine Q uinn. (2010). FoodWorks: A vision to improve NYC's food system. New York City Council, 2010. Retrieved from http:// ngfn.org/ resources/ ngfndatabase/ knowledge/ foodworks fullreport 1122 10.pdf

New York City D epartment for the Aging. (2016). Annual plan summary April 1, 2017-March 31, 2018. New York. Retrieved from http:/ / home2.nyc.gov/ html/ dfta/ downloads/ pdf/ D FTAAnnualPlanSummary2016.pdf

New York City D epartment of City Planning. (2008). G oing to mark et: N ew Y ork City's neighborhood grocery store and supermark et shortage [PowerPoint presentation]. New Y ork City: Author. Retrieved from http:/ / www.nyc.gov/ html/ misc/pdf/ going_to market.pdf

New York City D epartment of Education. (2016). School based expenditure reports, school year 2015-2016. Retrieved from https:/ / www.nycenet.edu/ offices/d chanc oper/ budget/ exp01/y2015 2016/ function.asp

New York City Economic D evelopment Corporation. (2016). Five borough food flow: 2016 N ew Y ork City food distribution \& resiliency study results. Retrieved from https:/ / www.nycedc.com/ system/ files/ files/ resource/ 2016 food supplyresiliency study results.pdf 
New York City Mayor's O ffice of Food Policy. (2012). 2012 Food Metrics Report. Retrieved from http:/ / www1.nyc.gov/ assets/ foodpolicy/ downloads/pdf/ l152-food-metrics-report-2012.pdf

Nir, S. M. (2016, January 23). Community gardens imperiled by New Y ork's affordable housing plans, N ew Y ork Times, p. A14.

O ffice of the Mayor of New Y ork City [NYC]. (2007). PlaNYC: A greener, greater New Y ork. 2007. Retrieved from http:/ / www.nyc.gov/ html/ planyc/ downloads/pdf/ publications/ full report 2007.pdf

Office of the Mayor of NYC. (2011). PlaNYC: A G reener, G reater New York, April 2011 Update. Retrieved from http:/ / www.nyc.gov/ html/planyc/downloads/pdf/publications/planyc_2011_planyc_full_report.pdf

O ffice of the Mayor of NYC. (2015). O ne NYC: The Plan for a Strong and Just City. Available at http:/ / www.nyc.gov/ html/ onenyc/ downloads/pdf/ publications/ O neNYC.pdf.

Office of the Mayor of NYC. (2017). Progress Report O neNYC 2017. Retrieved from http:/ / onenyc.cityofnewyork.us/wp- content/ uploads/ 2017/ 04/O OneNYC 2017 Progress Report.pdf

Office of the Mayor of NYC. (2018). The Fairest Big City in America. Retrieved from http:/ / www1.nyc.gov/ assets/ home/ downloads/ pdf/ press-releases/ 2018/ SOTC-2018-Book.pdf

Pires, S. M., Fidélis, T., \& Ramos, T. B. (2014). Measuring and comparing local sustainable development through common indicators: Constraints and achievements in practice. Cities, 39, 1-9. https:// doi.org/ 10.1016/ j.cities.2014.02.003

Prosperi, P., Moragues, A., Sonnino, R., \& D evereux, C. (2015). Measuring progress towards sustainable food cities: Sustainability and food security indicators. Report of the ESRC financed Project "Enhancing the Impact of Sustainable Urban Food Strategies. Retrieved from http:/ / sustainablefoodcities.org/ getstarted/ developingindicators

Raja, S. Ma, C., \& Y adav, P. (2008). Beyond food deserts measuring and mapping racial disparities in neighborhood food environments. Journal of Planning E ducation and Research, 27, 469-482. https:/ / doi.org/ 10.1177/ 0739456X 08317461

Roberto, C. A., Swinburn, B., Hawkes, C., Huang, T. T., Costa, S. A., Ashe, M., ... Brownell, K. D. (2015). Patchy progress on obesity prevention: emerging examples, entrenched barriers, and new thinking. The L ancet, 385(9985), 2400-2409. https:/ / doi.org/ 10.1016/ S0140-6736(14)61744-X

Sébastien, L., \& Bauler, T. (2013). Use and influence of composite indicators for sustainable development at the EUlevel. E cological Indicators, 35, 3-12. https:/ / doi.org/ 10.1016/ j.ecolind.2013.04.014

Talberth, J., Cobb, C. W., \& Slattery, N. (2007). The genuine progress indicator, 2006: A tool for sustainable development. O akland, CA: Redefining Progress. Retrieved from http:// ase.tufts.edu/ gdae/ CS/ G PI.pdf

Tegoni, C., \& Licomati, S. (2017). The Milan Urban Food Policy Pact: The potential of food and the key role of cities in localizing SD Gs. Journal of U niversities and International D evelopment C ooperation, 2017(1), 372-378. http:/ / www.ojs.unito.it/ index.php/ junco/ article/ download/ 2173/ 1984

Vitiello, D., \& Brinkley, C. (2014). The hidden history of food system planning. Journal of Planning H istory, 13(2), 91-112. https:// doi.org/ 10.1177/ 1538513213507541

Waas, T., Hugé, J., Block, T., Wright, T., Benitez-Capistros, F., \& Verbruggen, A. (2014). Sustainability assessment and indicators: Tools in a decision-making strategy for sustainable development. Sustainability, 6(9), 5512-5534. https:/ / doi.org/ 10.3390/ su6095512

Watershed Agricultural Council. (2017). C roton \& Catskill/ D elaware watersheds. Retrieved from http:/ / www.nycwatershed.org/ about-us/ overview/ croton-catskilldelaware-watersheds/

Willingham, C., Rafalow, A., Lindstrom, L. \& Freudenberg, N. (2017). The C U N Y Institute of U rban F ood Policy G uide to F ood G overnanœ in N ew Y ork City. CUNY G raduate School of Public Health and Healthy Policy. Retrieved from https:/ / static1.squarespace.com/ static/ 572d0fcc2b8dde9e10ab59d4/ t/ 5a0390059140b748e0e14a78/ 151018292423 5/ The-CUNY-Urban-Food-Policy-Insitute-Guide-to-Food-Governance-2017.pdf 


\section{Appendices}

Appendix 1. Selected Major New York City and State Food Policies, 2005-2017

2005. Shop Healthy and other later initiatives including Healthy Bodegas launched to improve quality and healthfulness of food in bodegas.

2006 .................... Launch of Health Bucks, a farmers market incentive program; expanded to all NYC farmers markets in 2012.

2007 ................... NYC Health Code updated to establish limits on sugary drinks served in child care centers; extended to summer camps in 2012.

2007 .................... Food Stamp Paperless Office System launched, allowing residents to apply for food stamps at partner food pantries and soup kitchens.

2007 .................... Ban on artificial trans fat in NYC restaurants.

2007 ................... Water jets installed in many NYC public schools to increase access to safe drinking water.

2007 ................... First food policy coordinator position established in Mayor's Office.

2008 .................... Green Carts, a new class of mobile fresh fruit and vegetable produce vendor permits, established for high-need areas.

2008.................... NY State expands SNAP eligibility, extends recertification.

2008 .................... Chain restaurants required to post calorie information on their menus or menu boards.

2008 ................... Online application for school meals implemented to facilitate enrollment.

2008 .................... Nutrition standards for all food purchased and served by city programs promulgated.

2008 .................... Garden to Café pilot in 20 schools, later expanded to "Grow to Learn," a citywide school gardening initiative.

2009................... Food Retail Expansion to Support Health (FRESH) program launched, providing incentives to attract grocery store development in underserved communities.

2009................. "Pouring on the Pounds" media campaign, encouraging New Yorkers to choose beverages with less sugar.

$2009 \ldots \ldots \ldots \ldots \ldots . . . . . .5$ SNAP call centers opened to increase access to information on program.

2010 .................... National Salt Reduction Initiative launched by NYC Department of Health to reduce sodium intake through voluntary corporate commitments announced.

$2011 \ldots \ldots \ldots \ldots \ldots . . . . . . . . N Y$ State ends requirement for finger imaging for SNAP.

2011 .................... Vending machine standards for food-dispensing machines in city buildings go into effect.

2012 .................... Local Procurement Guidelines encouraging agencies to buy New York State food products released.

2013.................... Food Waste Challenge announced asking NYC restaurants to commit to diverting $50 \%$ of their food waste.

2013 ................... Fruit and vegetable prescription pilot program launched at two city public hospitals; later expanded.

2013 .................... New York City Housing Authority launches first large-scale urban farm, later expanded to more sites.

2014 .................... New York City Food Assistance Collaborative created to increase emergency food availability and increase access to food and income assistance benefits for eligible New Yorkers.

2015 ................... Breakfast in the classroom programs expanded in NYC schools. 
Journal of Agriculture, Food Systems, and Community D evelopment

ISSN : 2152-0801 online

https:/ / www.foodsystemsjournal.org

2015 ................... Universal free school lunch implemented in most New York City middle schools, expanded to $90 \%$ of all New York City public schools in 2017.

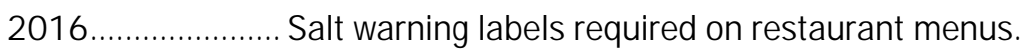

2016 ................... Minimum wage of New York City, New York State, fast food and other workers raised to US\$15 per hour to be implemented over three years.

2016 .................... Zero Waste Challenge (ZWC) invites New York City businesses to support the city's zero waste goals by working to divert at least $50 \%$ of their waste from landfill and incineration by the end of the challenge.

2016 and 2017 .... New laws to protect fast-food workers from unpredictable scheduling and payments.

2017. Approved for Universal Free Lunch in all NYC public schools.

Sources: Gearing, M. E., \& Anderson, T. (2014). Innovations in NYC health and human services policy: Food policy. Retrieved from the Urban Institute website: https:// www.urban.org/ research/publication/ innovations-nyc-health-and-human-services-policy-food-policy; Freudenberg, N., Cohen, N., Poppendieck, J., \& Willingham, C. (2018). Food policy in New York City since 2008: Lessons for the next decade. New York: CUNY Graduate School of Public Health and Health Policy. Retrieved from

http:// www.cunyurbanfoodpolicy.org/ news/2018/2/16/ food-policy-in-new-york-city-since-2008-lessons-for-the-next-decade 
Journal of Agriculture, Food Systems, and Community Development ISSN: 2152-0801 online

https:/ / www.foodsystemsjournal.org

Appendix 2. Indicators Included in Annual Food Metrics Reports (see abbreviations and explanations below)

1. Number of farms participating in the DEP Watershed Agricultural Program; Annual dollar amount of city financial support received by participating farms

2. Total DOE expenditure on local milk, yogurt, and produce, defined as produced in New York State

3. Registered community gardens on city-owned property

4. Food manufacturers receiving monetary benefits from EDC or IDA

5. Truck and rail trips to or through Hunts Point Market

6. Grocery store SF per capita and the number of grocery stores opened during the past five calendar years

7. Grocery stores receiving FRESH benefits

8. Number of stores participating in Shop Healthy

9. Number of food-related job training programs administered by SBS

10. Number of meals served in city institutional food programs

11. Compliance with food standards

12. Number of DOE vending machines and revenue generated

13. Number of seniors receiving SNAP benefits

14. Funds spent on SNAP enrollment by HRA

15. Funds spent on Nutrition Education by HRA: (a) Funds DOHMH Spends on Nutrition Education: Stellar Farmers' Market Initiative; (b) Funds DOHMH Spends on Nutrition Education: Eat Well Play Hard Program; (c) Funds DOHMH Spends on Nutrition Education: District Public Health Offices

16. (a) Salad bars in schools; (b) Salad bars in NYC Health and Hospitals facilities

17. Funds spent by DCAS on bottled water in 5-gallon containers and in single-serve bottles

18. Number of Green Cart permits, number of violations, locations, and number of operators that accept EBT

19. Number of vendors at GrowNYC farmers markets

$\begin{array}{ll}\begin{array}{l}\text { Abbreviations and explanations: } \\ \text { DCAS }\end{array} & \text { NYC Department of Citywide Administrative Services } \\ \text { DEP } & \text { New York City Department of Environmental Protection } \\ \text { DOE } & \text { NYC Department of Education } \\ \text { DOHMH } & \text { NYC Department of Health and Mental Hygiene } \\ \text { EBT } & \text { Electronic benefits transfer, a device that allows SNAP recipients to use SNAP card to pay for food } \\ \text { in stores and farmers markets } \\ \text { EDC } & \text { NYC Economic Development Corporation (a nonprofit corporation created by NYC) } \\ \text { FRESH } & \text { Food Retail Expansion to Support Health, a city program to encourage supermarkets to open or } \\ \text { Green Carts } & \text { expand in low-income neighborhoods } \\ \text { GROWNYC } & \text { NYC program to authorize vendors to sell fruits and vegetables on city streets in low-income } \\ \text { HRA } & \text { communities } \\ \text { Hunts Point Market } & \text { NYC nonprofit that administers many of the city's farmers markets and green markets } \\ \text { IDA } & \text { NYC Human Resources Administration, the city's social services agency } \\ \text { NYC Health + Hospitals } & \text { NYC's wholesale food market } \\ \text { SBS } & \text { The city's public hospital system } \\ \text { SF } & \text { Small Business Services, a city agency } \\ \text { Shop Healthy } & \text { Square feet } \\ \text { SNAP } & \text { NYC Department of Health program to encourage bodegas and grocery stores to sell healthier food } \\ & \text { Supplemental Nutrition Assistance Program }\end{array}$

Source: New York City Food Policy. (Various dates). Food metrics reports. Available at http:// www1.nyc.gov/ site/foodpolicy/about/ foodmetrics-report.page 